\title{
THE EFFECT OF TAXPAYERS' AWARENESS ON TAX COMPLIANCE CASE OF PRIVATE BUSINESS SECTOR IN BANADIR REGION, MOGADISHU-SOMALIA
}

\author{
Bashir Mohamed Abdulle \\ Lecture Assistant \\ Faculty of Economic and Management science \\ Somali National University \\ Columbia Rd, Hamar Weyne, \\ P.O Box15 Mogadishu-Somalia \\ Email: bashircabdulle@ snu.edu.so \\ Somalia
}

\section{ABSTRACT}

\begin{abstract}
Tax is very important in any country around the world. Since revenue collected from taxes enables a country to provide services to its citizens and for developmental progress as well. This study is about the effect of taxpayers' awareness on tax compliance of PBSs in the Banadir region and carried out with the scope of May 2018 to March 2019. The variables used in the study was the level of taxpayers' knowledge and tax law. While the study was explanatory research design the target population of 250 from the private business sector within the Banadir region. Data collected by administered questionnaire and were analyzed in descriptive statistics using statistical package for social science (SPSS20.0) and is presented in form of the frequency distribution of tables. It was also found a Correlation coefficient of a positive moderate degree of 0.637 and independent variables have enough explanations for the dependent variable with $R 2$ of $87 \%$ Thus, the study recommends there was a need for effective taxpayers' awareness programs to improve tax compliance. Also, to reduce corruption, improve accountability, and establish effective independent revenue authority.
\end{abstract}

\section{Keywords: Tax Compliance, Tax Awareness, Taxpayers, Private Business Sector(PBSs).}

\section{Introduction}

In the early years of the development of Islam, jizya and sadaqat were the main financial sources. After the obligation of Zakat in the second year Hijri, it converted the main source of revenue for the Islamic state. Zakat was charged on cash as well as on livestock, income, and resources as well.

Taxes were levy for the improvement in society in terms of education, development, infrastructure, etc. The scholars around the world agree that imposition of taxes is the right of the Islamic state to meet the needs of the poor as well as for running the affairs of the state distributing the wealth and stabilizing the state. (Pakeeza \& Qadoos,2017).

In Somalia, there has been political and economic instability for decades. Also, Somalia is defined as a fragile nation in every sector especially the economic situation is very poor because of the lack of effective and strong government that control the financial sector, and the big issue that most researchers address that Somalia is champions of corruption. Therefore, the taxpayers' compliance is very law because combined things to the whole Somali community in last three decays. Somalia's taxation rules were very hard in the regime era.
After the collapse of the Democratic Republic of Somalia in 1991 and at the same time law and order are out of the stage. (Rahman, 2017)

Educating people is critical to enhancing voluntary tax compliance. Lack of voluntary tax compliance requires revenue authorities to used costly and coercive methods for tax enforcement. Thus, taxpayers' education is a tool designed to enable taxpayers to understand tax laws and procedures. It involves the training of special units within the revenue departments, for providing education, analysis, and support to the taxpayers, through different media that include newspapers, television, radio programs, websites, seminars, and front small table help to publicize key information to the taxpayers. (Gitaru, Kelvin, 2017).

\section{Problem and Purpose}

In the last three decays, Somalia has listed the most corrupted nation in the world and nominated as a fragile state in the horn of Africa. Somali revenue authority suffers insufficient budget from the internal source to finance some priority of such government expenditures. One of the obstacles that may delay the effectiveness of tax collection is low taxpayer compliance. However, the main issue that faces the taxation system of Somalia is non-compliance among sectors of taxpayers in the context of Mogadishu. Although the Somali 
illiteracy rate is very high which means that the Somali population does not have enough knowledge to react in a positive way to all government actions including the tax imposed by the government. Tax laws has also major concerns that face policymakers in many post-conflict societies like Somalia. Everyone wants to be better off regardless of others and the government wants to equilibrate different classes of the community through taxation and social welfare.

Ministry of finance of the federal republic of Somalia makes the best that he can to improve different kinds of taxes but the issue is non-compliance because every taxpayer has its own beliefs about the tax system and where it is from and goes. Mostly there is a misunderstanding, low confidence between Somali tax authority and taxpayers of PBS in the Banadir region, so people would not want to comply, and now it is important to talk about if there is an effect of taxpayers' awareness on tax compliance in some selected sectors.

\section{Study questions}

This article seeks to answer these two questions written below and it will be the main road map of this study.

1. What is the relationship between the level of tax education and tax compliance in the Private business sector Banadir Region?

2. How tax laws affect tax compliance in the Private business sector Banadir Region?

\section{Study Methodology}

\section{The Scope Area of Study}

This study was made with the scope of the Banadir region in southern Somalia and at the same time, it is the capital city of Somalia which is the most economic concentration of the country and the most populated area of the nation which estimated more 3 million residents. Mogadishu is also where hosts all-important institution for the federal government of Somalia. What makes it very interesting to this topic is that the Banadir region is the only region that generates public revenue more than others. Also, the Banadir region faces both two layers of taxation regional and federal levels.

Research Design

This study adopted an explanatory research design that was used to know the cause of the problem and the linkage between the variables. It explains the nature of the problem

\section{Sample and Sampling strategy}

For this study, the population may involve a large number that was hard to be studied in all at once.

Therefore, the study was considering sample analysis. The sample was a subset of the whole individuals and the sample size was 153 taxpayers in the private business sector in the Banadir region. The reason for taking the sample size formula was to decrease research errors and too far from research bias. The sample size strategy used was a sampling equation that was called Solvin's formula which was most applicable to this kind of study.
Taxpayers' education program is one of the approaches of cultivating service transfer to the taxpayers. (News, 2019)

Another key problem this study wants to cover is lack of awareness in the taxpayers' sector because the PBSs area would not sure that the money they paid will use in the proper way such as building roads, free education, free health service, and reliable social security. The federal government of Somalia stressed several challenges from a member of federal states to make unique taxation in whole the country and the capacity of the central government Somalia is limited to the specific area and approximately $20 \%$ of Somali territory is under the hands of the Al-Shabaab militants. So, this paper will focus on the effect of taxpayers' awareness of tax compliance in the private business sector in the Banadir region.

this research to make conclusions on the population being studied and it is used quantitative data. This study was facilitated by just two persons a researcher and Supervisor who work closely with one another with the timeframe between March 2018 to March 2019.

\section{Target Population}

The population under this study was being taxpayers' private business sectors in Banadir region Mogadishu Somalia. The study only focused on the taxpayers in the private business sector area such as Hotels, telecommunications industry, financial institutions, water and energy companies, Smallmedium enterprises. The target population in this study was 250 from the private business sector in the Banadir region that is owned by Somali people and registered as a taxpayer in the tax department for the ministry of finance of the federal government of Somalia. Thus, the whole population was difficult to study according to scope, then the study took the sample from the population and the inclusion criteria was being the taxpayers those registered the tax department in the ministry of finance of the federal government of Somalia. Therefore, the research findings from the sample frame were judging the true populations to take some important policy implications.

Formula $\mathrm{n}=\frac{N}{1+N(e) 2}$

Where:

$\mathrm{n}=$ represents the sample size

$\mathrm{N}=$ Population size

$\mathrm{e}=$ Marginal error

Then $\frac{250}{1+250(0.05) 2}=153$ persons.
Note

$\mathrm{N}=250$

$\mathrm{n}=153$

$\mathrm{e}=5 \%$

\section{Data collection instrument}

This study involved various peoples' awareness. The main tool used was a questionnaire to collect primary data 


\section{(C) Center for Promoting Education and Research (CPER) USA}

www.cpernet.org

because most of this research was conducted with primary data in the required information from the participants and also the mode of the questionnaire was close-ended questions to secure the objective of the study. The questionnaire was dividing into sections from the personal data to the last objective.

The instrument was structured modified Likert scale to make a range of degree on four dots strongly agree (SA) through agree (A), Disagree (D) to Strongly Disagree (SD) and the main goal was to know responses in the degree of agreement in the statement. In this study was carried out a pilot study or pre-test of the questionnaire that means before actual research to ensure the viability of the study and that questionnaire measure what to measure the objective of the study.

\section{Data quality control}

The questionnaire planned for the study was showing to a validation process for Face validity and content validity. Face validity was the idea that a test should appear superficially to test what it was supposed to test while Content validity was the idea that a test should sample the range of behavior represented by the theoretical concept. The validity of this data was well accurate because the source was reliable and well recognized. This investigation was well acknowledged in all sources of the study.

Also, the researcher made a pre-test for the questionnaire and distributed 10 papers to people who considered highly professionals $80 \%$ agree that this questionnaire was going to measure what the research was talked about. So the validity of the study is fully controlled with the frame of investigated questions.

\section{Data analysis and presentation tools}

The investigation was taking place in form of quantitative analysis. The data collected from the field were analyzed with the assistance of the Statistical Package for Social Science Version 20.0 (SPSS 20.0).

Descriptive statistics were used to answer research questions and make tendency measurements such as weighted mean, standard deviations, and different percentages of the sample.

Also, it was used correlations analysis because of the degree of dependence between the variable under been investigation because it was must to know signs and the direction of interrelating between variables and the objective of the whole study. The descriptive analysis is also used to draw statistical inferences on the variables and then make the meaningful economic interpretation that will lead to significant policy implications. The study presents result in form of numerical interpretation, Graphics, and tables to summarize the data clearly and reasonably.

\section{Ethical considerations}

All privacy and confidentiality of data used in this study and the information were only used for research purposes, academic decision-making, and professionalism. This paper was fully conducted ethically and insured all sensitive issues. Also, the way of referencing was fairness and the researcher mentioned all authors and did not make any override of the different opinions. Therefore, the study was far from self-interest and study bias that can lead to direct plagiarism by telling false ownership of such sentence.

\section{Limitations}

While Somalia was considered a post-conflict society and there was a lack of effective system around 28 years. The most important variable that is worldwide accepted was that the data proxy of economic variables was missing in Somalia and some documents were the hand of such institutions and not shareable because of safekeeping matters and confidentiality, thus one of the restrictions of this study was that the availability of previous studies. Another constraint or key problem was lack of financial support because every step forward incurred cost and the researcher does not have any budget to manage all costs of the study. Consequently, the study population was less informed about the concept of taxation and it was so hard to understand and they could not give the essential information required to carry on smoothly the research.

\section{Conceptual Framework}

The study was used this theoretical framework to explain graphically, or in narrative form. It is used to structure a subsequent presentation and the relationship between the independent variable and the dependent variable. The figure below shows how knowledge and awareness affect tax compliance. So tax compliance stands for the dependent variable which was measured from the understanding and awareness of taxation in PBSs in a form of publications such as seminars and workshops, newspapers, and magazines that conducted by the Somali Revenue Authority.

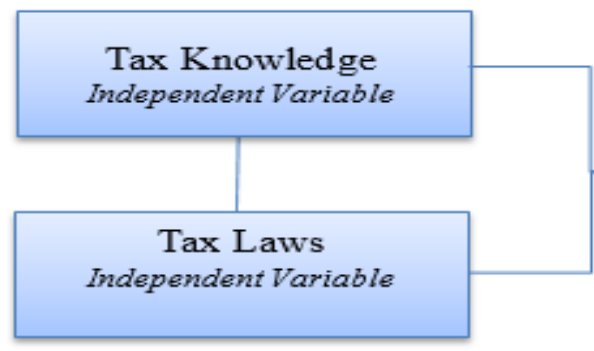

Tax Compliance

Dependent Variable 


\section{CCenter for Promoting Education and Research (CPER) USA}

\section{Discussion and Findings}

The main purpose of this study was to investigate the effect of taxpayers' awareness on tax compliance in the private business sector in the Banadir region. To achieve those declared objectives of the study questionnaire were employed in this research. Data were collected from different markets places in the Banadir region especially the Private business owned by Somali people. The questionnaire consists of 25 questions that have been used for collecting general information and relevant questions about the research objective from the respondents.

In order to gather competently the information of our objective the researcher goes to the different locations of the business and allocated to distribute 153 papers of the questionnaire which was the sample size of the study. Survey the number of papers returned was 146 papers because 7 papers were lost in the data collection process which means $95 \%$ of the questionnaire was filled successfully and returned.

Demographic Information of the respondents

The data comes from the private business sector owned by Somali people who registered the Somali tax department in the ministry of finance of the federal republic of Somalia. The introductory part of the research questionnaire was well organized and the respondents have been given full confidence that all data they were provided will use only for academic research and preserved confidentiality.

Table. 1 Gender of the respondents

\begin{tabular}{|ll|l|l|l|l|}
\hline & & Frequency & Percent & Valid Percent & Cumulative Percent \\
\hline \multirow{3}{*}{ Valid } & Male & 92 & 63.0 & 63.0 & 63.0 \\
& Female & 54 & 37.0 & 37.0 & 100.0 \\
& Total & 146 & 100.0 & 100.0 & \\
\hline
\end{tabular}

Source: SPSS Primary data 2019

Table: 1 above shows that the respondents in this study 92 of Therefore, the number of males in the respondents was greater them were male which means $63 \%$ of the total respondents than the number of females in this study.

while the other 54 were female in gender which is $37 \%$.

Table:2 Age of the respondents

\begin{tabular}{|ll|l|l|l|l|}
\hline Age & Frequency & Percent & Valid Percent & Cumulative Percent \\
\hline \multirow{4}{*}{ Valid } & Under 25 & 20 & 13.7 & 13.7 & 13.7 \\
& $26-34$ & 31 & 21.2 & 21.2 & 34.9 \\
& $35-44$ & 73 & 50.0 & 50.0 & 84.9 \\
& $45-54$ & 22 & 15.1 & 15.1 & 100.0 \\
\hline
\end{tabular}

Source: SPSS Primary data 2019

Age is a demographic variable, which can be, between the ages of 45 to 54 which means $15 \%$ of the whole distinguished from the respondents because age can influence respondents.

the behavior of the people. Therefore, the above table: 2 Shows that 20 people of the respondents were age under 25 which is $13.7 \%$ of all respondents and 30 of them also were age between 26-34 that equivalent to $20.5 \%$ of whole respondents. Also, 74 of the people under this investigation were aged $35-44$. Which is $50 \%$ of the respondents that shows the majority was under this age. Lastly, 22 of them were
Therefore, the conclusion of the above figure tells that almost $50 \%$ of the respondents were the age of 35-44, which indicates that private business people are still young and they are still middle age concerning the age of retirement, although Somalia people did not consider retirement age because there are no pension funds to them.

Table: 2 Level of Education of the respondents

\begin{tabular}{|l|l|l|l|l|}
\hline & Frequency & Percent & Valid Percent & Cumulative Percent \\
\hline Secondary Certificate & 26 & 17.8 & 17.8 & 17.8 \\
Diploma & 36 & 24.7 & 24.7 & 42.5 \\
Bachelor & 66 & 45.2 & 45.2 & 87.7 \\
Master & 16 & 11.0 & 11.0 & 98.6 \\
PhD & 2 & 1.4 & 1.4 & 100.0 \\
Total & 146 & 100.0 & 100.0 & \\
\hline
\end{tabular}




\section{CCenter for Promoting Education and Research (CPER) USA}

WWW.cpernet.org

The level of education of the respondents is another key factor that the researcher wants to know to make meaningful full analysis in this study. After analysis of the SPSS in the questionnaire, 26 persons in the sample were at a secondary level that is $17.8 \%$ in the percentage of the respondents. And 36 of them also were diploma that means $24.7 \%$ of whole respondents and also 66 of them were bachelor degree which covers $45.2 \%$ of the entire sample and then 16 of them were a master degree that reveals $11 \%$ of the total and last 2 of the respondents have Ph.D. and cover only $1.4 \%$. The educational background of the people was so different numbers and most respondents of this questionnaire graduate. So all those under this survey have a self-educational background but they needed a tax awareness program as an education package.

\section{Table:4 Work Position}

\begin{tabular}{|ll|l|l|l|l|}
\hline & & Frequency & Percent & Valid Percent & Cumulative Percent \\
\hline \multirow{4}{*}{ Valid } & Owner & 43 & 29.5 & 29.5 & 29.5 \\
& Top Manager & 35 & 24.0 & 24.0 & 53.4 \\
& Employee & 68 & 46.6 & 46.6 & 100.0 \\
& Total & 146 & 100.0 & 100.0 & \\
\hline
\end{tabular}

Source: SPSS Primary data 2019

The people who filled the questionnaire the entire are working in different position in different small-medium enterprises but they are differing in percentage. In table4 of these study shows that 43 of the respondents were owners who run their business solely and they cover $29.5 \%$ of the completely surveyed people in Mogadishu taxpayers, secondly 35 of them were also top management of the business who separate from the ownership of the companies and their percentage according to all respondents were also $24 \%$. Finally, most parts of the respondents were employees whose number was 68 of all questioned people were employee level, and equivalent to $46.6 \%$ of the total respondents. However, the result states that the private business people in the Banadir

Table:5 Reliability Statistics region were most of the members of staff rather than owners and managers.

\section{Reliability Statistics}

Data reliability was very important because it is a way of assessing the quality of the measurement procedure used to collect data in the study. For the results of a study to be considered valid, the measurement procedure must first be reliable.

The researcher analyses data reliability statistics in SPSS-20 for the objectives of the study. Reliability analysis is also very important for every research because the readers get more reliable in the reading process. The reliability test defines the reliability of a questionnaire representing a variable, the test shows that it was categorized into the highly reliable level.

\begin{tabular}{|l|l|l|}
\hline Cronbach's Alpha & \multicolumn{1}{|c|}{ Objective } & Rule/comment \\
\hline .814 & $\begin{array}{l}\text { Relationship between taxpayers' awareness and tax compliance } \\
\text { of private business sector in Banadir region ,Mogadishu } \\
\text { Somalia }\end{array}$ & Accepted \\
\hline
\end{tabular}

Source: SPSS Primary data 2019

Reliability was measured using Cronbach's Alpha coefficient that was used to determine the internal consistency of the study measures. The Cronbach's alpha coefficient ranges between 0 and 1 and alpha coefficients of a minimum of 0.70 are considered appropriate. The overall Cronbach's alpha coefficients for all the constructs in this study were 0.814 . The study measures were found to be highly reliable in that they all had an alpha coefficient greater than the minimum accepted Cronbach's alpha coefficient of 0.70 . Therefore, by looking at each objective of our study the effect of taxpayers' awareness on tax compliance in the private business sector, Mogadishu Somalia.

\section{Tax registration}

In this part, the researcher looks for all questions about the tax registration process to know that private business sector taxpayers in the Banadir region have the same registration forms. The time of registration also is very important, tax payment methods and the medium they should pay. Because taxpayer's registration could enhance the tax compliance of the taxpayers of PBSs in the Banadir region, Therefore the researcher asked the respondents such question that related the TIN, year of registration, payment method, and lastly medium of tax payment that Mogadishu taxpayers use to pay their tax obligations. Therefore, in the following charts, the researcher made a presentation of the research findings and results. 
The low ownership TIN, not timely payment of taxes, which is unique for each taxpayer. TIN facilitates not timely in the delivery, and are not willing to pay taxes is an governments' computerized tax administrations and this indicator that represents the individual tax compliance. eliminates as many as a variety of numbers that the revenue Perception of the taxpayers on the tax obligations shows the department uses for each taxpayer. So all taxpayers who run degree of willingness of taxpayers in performing the business with the revenue department must have a TIN obligations naturally in the individual under applicable because registration documentation will be issued with the regulations. However, this awareness is still limited to the taxpayers' unique number and it is very important because it attitude of the taxpayer on the implementation of tax laws. Tax must be used on all tax matters done on their behalf as an registration number has many benefits in which legally can identifier.

protect the taxpayers and mostly it comprises at least 9-digits,

\section{Table:6 Tax Identity Number (TIN) from tax authority.}

\begin{tabular}{|ll|l|l|l|l|}
\hline & & Frequency & Percent & Valid Percent & Cumulative Percent \\
\hline \multirow{4}{*}{ Valid } & Yes & 45 & 30.8 & 30.8 & 30.8 \\
& No & 101 & 69.2 & 69.2 & 100.0 \\
& \multirow{2}{*}{ Total } & 146 & 100.0 & 100.0 & \\
\hline
\end{tabular}

Source: SPSS Primary data 2019

The respondent was also asked that they have a TIN. So the above Table also shows that taxpayers in PBSs of the Banadir region almost do not have tax identity number (TIN) and at the same time, they paid different types of taxation. As result, 69\% of the total respondents do not have TIN numbers from the Somali government in the department of taxation while only $31 \%$ have TIN. Therefore without having TIN the taxpayers' compliance is very low because it is easy to evade tax burden and the conflict between the revenue department and the business holder will exist until all businesses have secured an accurate TIN. In that, stage both sides will be underwritten rules and regulations, and sometimes government looks at all data about each taxpayer according to their TIN, because it provides all information and can be proxy when the governments want to pay back such as subsides.

\section{Table:7 What type of tax did PBS paid?}

\begin{tabular}{|ll|l|l|l|l|}
\hline & Frequency & Percent & Valid Percent & Cumulative Percent \\
\hline \multirow{4}{*}{ Valid } & Income tax & 18 & 12.3 & 12.3 & 12.3 \\
& Sales tax & 45 & 30.8 & 30.8 & 43.2 \\
& Property tax & 64 & 43.8 & 43.8 & 87.0 \\
& Lamp sum & 19 & 13.0 & 13.0 & 100.0 \\
& Total & 146 & 100.0 & 100.0 & \\
\hline
\end{tabular}

Source: SPSS Primary data 2019

Table:7 shows that most taxpayers have been paid property tax about only their private property because when it comes to instead of sales tax and income tax. Approximately $44 \%$ of the total respondents were paid property tax while around $31 \%$ have paid sales tax, but the problem here is that most of those property tax they paid more while other forms of taxation were very low payment. The only reason that worldwide accepted is e that people always like to have their own private property respondents do not have a TIN number. This also shows that rather they have to work with other people's property. This Private businesspeople in the Banadir region mostly cared reveals many economic theories that criticize private property.

Table:8 Medium of Awareness programs from Somali tax authorities

\begin{tabular}{|ll|l|l|l|l|}
\hline Medium & & Frequency & Percent & Valid Percent & Cumulative Percent \\
\hline \multirow{4}{*}{ Valid } & Work shop & 34 & 23.3 & 23.3 & 23.3 \\
& Newspaper & 13 & 8.9 & 8.9 & 32.2 \\
& TV/Radio & 99 & 67.8 & 67.8 & 100.0 \\
& Total & 146 & 100.0 & 100.0 & \\
\end{tabular}




\section{(C) Center for Promoting Education and Research (CPER) USA}

www.cpernet.org

Table: 8 shows the channels that the tax officials tried between the tax officials and the taxpayers which can be most to give awareness programs to the taxpayers. The tax effective and efficient program. Although 13 people who run authorities have many ways to inform their stakeholder different business in Mogadishu which $8.9 \%$ of the total including taxpayers but all channels have no single objective community were got information in the form of newspapers, and their response and efficiency are not the same means that while 99 of the respondents get medium on TV/Radio the success of the strategy depends on the medium was used programs which as percentage $67.8 \%$ of the whole and how it was used. As a result of this table, 34 of the respondent's people who runs the private business in respondents got the awareness program the workshop Mogadishu. Those are the most people of the business under conducted by the Somali tax administrations and were $23.3 \%$ this survey and it shows that most of the respondents have not of the total respondents in this research and this were meetings got a chance to tell their compliant on the tax issues.

Table:9 Have they committed any tax penalty from the tax department

\begin{tabular}{|ll|l|l|l|l|}
\hline & & Frequency & Percent & Valid Percent & Cumulative Percent \\
\hline \multirow{3}{*}{ Valid } & Yes & 8 & 5.5 & 5.5 & 5.5 \\
& No & 138 & 94.5 & 94.5 & 100.0 \\
& Total & 146 & 100.0 & 100.0 & \\
\hline
\end{tabular}

Source: SPSS primary data 2019

The table above shows that the taxpayers in the private business sector in the Banadir region under this survey have no committed any tax penalty from the tax officials. Their answer indicates only 8 respondents which in percentage reaches 5.5\% have committed tax penalty from the tax department while 138 of them were said that they did not get any penalty on their non-compliance or tax evasion and this equivalent $94.5 \%$ of the whole respondents. However, this shows the weakness of the tax law enforcement in the department of taxation of BSs in the Banadir region and also lack of the high capacity legal institutions.
Question one: the relationship between the level of tax education and tax compliance in PBSs?

In this section, the respondents asked six questions, which related to this question mark and the questionnaire was designed to describe the need for taxpayers' knowledge on tax compliance whether taxpayers in the Banadir region have enough understanding to follow the tax rules and regulations or not. This analysis will find how the taxpayer could be in full compliance. The below table will summarize how awareness programs affect the taxpayers' compliance in the private business sector in the Banadir region.

Table: 10 The relationship between level of tax education and tax compliance in PBSs

\begin{tabular}{|l|l|l|}
\hline \multicolumn{1}{|c|}{ Six question asked for the respondents } & Mean & S.D \\
\hline Are you aware any taxpayers' awareness program by tax department? & 1.59 & .494 \\
\hline Does awareness program by Somali tax department was educative? & 2.12 & .946 \\
\hline Can workshops from tax authority would lead payment on time? & 2.68 & .878 \\
\hline How seminars would increase the taxpayers knowledge? & 2.60 & .907 \\
\hline Do the tax division teaches the taxpayer how to calculate the tax rates? & 2.52 & .941 \\
\hline Can awareness programs change taxpayers attitude on taxation? & 2.47 & .998 \\
\hline Overall Mean & $\mathbf{2 . 3 3}$ & $\mathbf{0 . 8 6}$ \\
\hline
\end{tabular}

Source: SPSS primary data 2019

The first purpose of the investigation was to describe the relationship between the level of taxpayers' awareness and tax compliance in PBSs, Somalia. As a result, while the investigator was analyzed questions under this objective since the overall mean index (2.33) and Standard deviation of (0.861) make interpretations that on average the business people "agree" there is an effect of taxpayers' awareness on tax compliance in Mogadishu.

Question two: How tax laws affect the tax compliance of the taxpayers in the PBSs Banadir Region?

The researcher examined the respondents two important questions about tax laws and how they contribute to tax compliance. The first question asked the surveyed business people was that did they commit any tax penalty from the taxing unit. According to the answer, they give almost $95 \%$ of them did not commit any kind of tax punishment, so this contributes that low compliance could also be a source of lack of law enforcement on taxations. The second question also was did both taxpayers and tax collectors respected Somali tax laws? However, the result of this question showed a mean of (2.12) and a standard deviation of (0.898) denotes that respondents "Agree" which means the tax collectors from the Somali tax department did not respect the Somali tax laws. Therefore, tax laws have also an effect on tax compliance. 
Table:11 Correlations analysis

\begin{tabular}{|ll|l|l|}
\hline & & Taxpayers' Awareness & Tax Compliance \\
\hline \multirow{5}{*}{ Taxpayers' Awareness } & Pearson Correlation & 1 & $.637^{* *}$ \\
& Sig. (2-tailed) & & .004 \\
& $\mathrm{R}^{2}$ & $0.87^{*}$ & $0.87^{*}$ \\
& $\mathrm{~N}$ & 146 & 146 \\
& Pearson Correlation & $.637^{* *}$ & 1 \\
Tax Compliance & Sig. (2-tailed) & .004 & \\
& $\mathrm{R}^{2}$ & $0.87^{*}$ & $0.87^{*}$ \\
& $\mathrm{~N}$ & 146 & 146 \\
\hline
\end{tabular}

Source: SPSS primary data 2019

**. Correlation is significant at the 0.05 level (2-tailed).

*. Coefficient Determination $\mathrm{R}^{2}$ at the level (2-tailed)

This analysis of correlation showed that the level of taxpayers' knowledge is positively related to the taxpayers' awareness to calculate correctly the tax compliance with the R2 of 0.87 that implies that the independent variables are suitable to predict the effect on the dependent variable. According to the correlation coefficient of 0.637, the independent variables affect a moderate degree to the dependent variable and the sign shows positivity and the direction of the relationship.

\section{Conclusion}

Come to the last of this stage concludes that the aims of the study were found it has existed in the context of PBSs in Banadir region and the study questions were assessed what is to be intended to reach. After analysis, it was also found there is a research gap needed to fulfill. Therefore, the two purposes of this study showed there was a need for a public awareness program and to regulate the PBSs in the Banadir region. So the taxpayers' compliance was very low because of the lack of effective legal institutions. Also, the level of knowledge of individuals was crucial to tax compliance. Last, this study will indicate such advice to the interested party in the context.

\section{Recommendations}

The study makes some notable suggestions to all stakeholders including government officials and regional authorities. 1st all levels of the education system of the country should be included in such compulsory courses like taxation and civic education because everyone will be ready and believe paying tax is important for him or her and the community as well. 2 nd the establishment of a powerful independent Somali Revenue Authority "SRA" is very important that guides, controls, collect tax revenues from the different taxpayers in different regions of both federal and state levels. This also will reduce corruption matters in the public financial system. $\mathbf{3 r} \boldsymbol{d}$ as matter of fact the giving award to taxpayers in a particular time in which the department of tax administration granted compliance certificate to the best taxpayer of the year ended. So the taxpayers become motivated and they feel paying tax has incentives to themselves. Lastly, the study indicates that there could be other factors, that influence tax compliance by PBSs in Mogadishu Somalia. Therefore, the researcher recommends an additional study on other factors like attitude and perception of taxpayers, the effect of technology, cultural diversity of the communities, and online tax filing on tax compliance.

\section{References}

Abeler, J., and S. Jäger. "Complex tax incentives." American Economic Journal: Economic Policy, vol. 7, no. 3, 2015, pp. 1-28, doi:10.1257/pol.20130137.

Ahmad, N. "Tax compliance cost among Smes: Evidence from the southern region of Malaysia." 2018, doi:10.15405/epsbs.2018.07.02.16.

Alm, J., et al. "Enforcement, socioeconomic diversity, and tax filing compliance in the United States." Southern Economic Journal, vol. 82, no. 3, 2016, pp. 725-747, doi:10.1002/soej.12106.

Ameyaw, B., and D. Dzaka. "Determinants of tax evasion: Empirical evidence from Ghana." Modern Economy, vol. 07, no. 14, 2016, pp. 1653-1664, doi:10.4236/me.2016.714145.

Dallal, A. "The Islamic institution of waqf:." Islam and Social Policy, 2004, pp. 13-43, doi:10.2307/j.ctv17vf6q5.4.

Dibie, R., and R. Dibie. "Analysis of the determinants of tax policy compliance in Nigeria." Journal of Public Administration and Governance, vol. 10, no. 2, 2020, p. 34, doi:10.5296/jpag.v10i2.16934. 
Gitaru, Kelvin (2017): The Effect of Taxpayer Education on Tax Compliance in Kenya , 2013, pp. 13-65, doi:10.1007/978-94007-7476-6_2.

HELHEL, Y., and M. VARSHALOMIDZE. "Determinants of tax attitude and tax compliance among small and medium enterprises (SMEs) in tourism industry: A survey study in Georgia." Archives of Business Research, vol. 3, no. 5, 2015, doi:10.14738/abr.35.1495.

Jaafar Sidik, M. H., et al. "Examining the influence of fairness perception on tax compliance behavior of the Libya individual taxpayers: The moderating tax awareness and tax complexity." Humanities \& Social Sciences Reviews, vol. 7, no. 2, 2019, pp. 519-525, doi:10.18510/hssr.2019.7261.

Lee, H. C. "Can electronic tax invoicing improve tax compliance? A case study of the Republic of Korea's electronic tax invoicing for value-added tax." Policy Research Working Papers, 2016, doi:10.1596/1813-9450-7592.

Obaid, M. M., et al. "An investigation of the determinants of tax compliance among yemeni manufacturing SMEs using the Fisher model." International Journal of Psychosocial Rehabilitation, vol. 24, no. 04, 2020, pp. 1809-1824, doi:10.37200/ijpr/v24i4/pr201289.

"Perspectives on SMEs and tax compliance." 2016, doi:10.1787/9789264256200-5-en.

"Somali government steadily ramping up tax collection." 10 Dec. 2019, www.youtube.com/watch?v=-bJ0mb5L1PM.

"Somalia GDP | 1960-2019 data | 2020-2022 forecast | Historical | Chart | News." 2019, tradingeconomics.com/somalia/gdp.

Suyanto, S., and E. Trisnawati. "The influence of tax awareness toward tax compliance of entrepreneurial taxpayers and CELENGAN PADJEG program as a moderating variable: A case study at the Pratama tax office of Wonosari town." INFERENSI, vol. 10, no. 1, 2016, p. 47, doi:10.18326/infs13.v10i1.47-68.

Waluyo, W. "The effect of addition of taxpayers number, tax audit, tax billing, and taxpayers compliance toward tax revenue." The Accounting Journal of Binaniaga, vol. 1, no. 1, 2018, doi:10.33062/ajb.v1i1.75.

Wicaksono, M., and T. Lestari. "Effect of awareness, knowledge and attitude of taxpayers tax compliance for taxpayers in tax service office boyolali." International Journal of Economics, Business and Accounting Research (IJEBAR), vol. 1, no. 01, 2017, doi:10.29040/ijebar.v1i01.236. 